Bangladesh J. Bot. 48(4): 1207-1213, 2019 (December)

\title{
GENETIC INTERRELATIONSHIP AMONG YIELD AND ITS COMPONENTS IN RICE HYBRIDS
}

\author{
Md Jamil Hasan*, M Umma Kulsum, Shaikh Jafar Mohiuddin ${ }^{1}$ \\ AND MD ZAHID-AL-RAFIQ ${ }^{2}$ \\ Hybrid Rice Division, Bangladesh Rice Research Institute, Gazipur-1701, Bangladesh
}

Keywords: Correlation coefficient, Genetic advanced, Heritability, Variability, Hybrid rice

\begin{abstract}
The present investigation was conducted to elucidate the interrelationship among various yield and yield contributing traits. Among the traits plant height, days to $50 \%$ flowering, days to maturity, filled grain per panicle and spikelet sterility showed high genotypic variance. Effective tillers per hill, filled grain per panicle, spikelet sterility had high genotypic coefficient of variation with high heritability and high genetic advance per cent of mean. Effective tillers per hill, panicle length, filled grain per panicle and 1000-grain weight exhibited significant positive association with grain yield. Path coefficient analysis also revealed that plant height, effective tillers per hill, panicle length and 1000-grain weight had higher direct effect on rice yield ( $\mathrm{t} / \mathrm{ha}$ ). Days to $50 \%$ flowering, days to maturity and spikelet sterility possessed moderate to low negative direct effect on rice yield. All together with the genetic variability, correlation and path analysis revealed that plant height, effective tillers per hill, panicle length, filled grain per panicle and 1000-grain weight were the most important yield component in rice hybrids.
\end{abstract}

\section{Introduction}

The population of Bangladesh is growing @ 1.22\% and the total population will be 233.2 million in the next 40 years if the current trend continues (Kabir et al. 2015). Therefore, Bangladesh will require more than 57.0 million tons of rice to feed its people by the year 2050 . During this period land, labor and water will be decreased due to urbanization. One needs to support this increasing population to produce more food with less land, less labor and less water. So, the development of high yielding rice variety might be the possible way and hybrid rice is one of best available technological option to increase yield. Yield contributing components are interrelated with each other expressing a complex chain of relationship and highly influenced by environmental conditions (Prasad et al. 2001), hence direct selection for yield alone limit the selection efficiency and ultimately results in limited success in yield improvement.

Knowledge about the genetic variability and interrelationship among the yield and yield contributing traits are important. Yield can possibly be improved through the knowledge of interrelationship among various yield contributing traits along with direct and indirect influence of component characters on yield. This helps in the prediction of correlated response to differential selection and detection of traits that serve as useful indicators of the more important ones under consideration (Johnson et al. 1955a). Path coefficient analysis partitions into direct and indirect matrix presenting correlation in a more meaningful way (Mohsin et al. 2009). The direct and indirect effects of different traits on grain yield were also studied which may help in determining the component traits affecting yield potential. Based on this information an effective selection program can be proposed for the genetic improvement of rice hybrid.

\footnotetext{
*Author for correspondence: <jamilbrri@yahoo.com>. ${ }^{1}$ Seed Processing and Preservation Center, Supreme Seed Company Limited, Trishal, Mymensingh, Bangladesh. ${ }^{2}$ BJRI, Rangpur Regional Station, Rangpur, Bangladesh.
} 


\section{Materials and Methods}

Fifteen exotic and two locally developed hybrid rice varieties were evaluated at the Bangladesh Rice Research Institute (BRRI), Gazipur during the year 2016-17 under irrigated rice ecosystem using RCB design with three replications. Thirty days old seedlings were transplanted in $10 \mathrm{~m}^{2}$ areas using single seedling per hill. Fertilizer doses were 80: 60: $40 \mathrm{~kg} \mathrm{~N} \mathrm{P} \mathrm{K} \mathrm{and} 70 \mathrm{~kg}$ gypsum per hectare. Except $\mathrm{N}$ all other fertilizers were used as basal dose and $\mathrm{N}$ fertilizer was top dressed in three equal splits at 15, 30 and 45 days after transplanting. Standard crop management practice was done as and when needed. Data on plant height (cm), days to 50\% flowering (days), effective tillers per hill (no), panicle length $(\mathrm{cm})$, days to maturity (days), filled grain per panicle (no), spikelet sterility (\%), 1000-grain weight (g) were taken from randomly selected ten plants of each plot. Yields were taken from whole plot crop cutting and converted to ton per hectare.

The data were analyzed by MSTAT program for ANOVA. The mean sum of square (MSS) of error considered as error variance $\left(\sigma^{2} \mathrm{e}\right)$, phenotypic variance $\left(\sigma^{2} \mathrm{p}\right)$, genotypic variance $\left(\sigma^{2} \mathrm{~g}\right)$, broadsense heritability $\left(\mathrm{h}^{2}{ }_{\mathrm{b}}\right)$ and genetic advance in per cent of mean (GAPM) were estimated (Johnson et al.1955a). GCV and PCV were estimated according to the formula of Burton (1952). Genotypic and phenotypic correlation coefficients were measured using formula suggested by (Miller et al. 1958). The correlation coefficient was further partitioned into components of direct and indirect effects by path coefficient analysis developed by Wright (1934) and later described by Dewey and Lu (1959).

\section{Results and Discussion}

The analysis of variance revealed significant differences among the varieties for all the characters studied. The mean sum of squares due to varieties was significant for all the characters that the genotype selected were genetically variable and considerable amount of variability existed among them (Table 1). It indicates ample opportunity for rice improvement selecting different quantitative characters. Similar results were reported by Sharma and Sharma (2007) in rice.

Variability plays a vital role for the selection of superior genotypes in crop improvement program. Distinct variation in the breeding materials is prerequisite for development of varieties with existing demand. Actual genetic variation may be masked by its environmental influence. Therefore, partitioning the phenotypic variation into genotypic and environmental effects is essential for selection of suitable genotypes. The genotypic variance was the highest for filled grain per panicle (328.75) followed by spikelet sterility (115.50) indicating greater scope of selection (Table 1). Plant height, days to 50\% flowering, effective tillers per hill, panicle length, days to maturity and 1000-grain weight exhibited desirable genotypic variance creating better scope of selection. On the other hand, the lowest genotypic variance was found for yield. The phenotypic variance for all the traits were little bit higher but close to the genotypic variances indicating preponderance of additive gene effects for these traits. Genotypic coefficient of variation (GCV) considers the best relative amount of genetic variation and it takes into account the mean value as well as the unit of measurement. Genotypic coefficient of variation values ranged from 3.23 to $29.87 \%$. The PCV values showed similar trends as GCV values and ranged from 4.15 to $30.25 \%$. The values of PCV were little bit higher but close to the corresponding GCV values for all the traits (Table 1).

The small differences between PCV and GCV for all the traits indicated that the variability was predominantly due to genotypic differences, i.e. little environmental influences. Similar results have also been reported by (Sameera et al. 2016). Days to maturity, days to $50 \%$ flowering and plant height had low coefficient of variation, which validated the chances of getting substantial gains under selection are possibly to be less for these traits. Whereas, high values of 
coefficient of variation for effective tiller per hill, panicle length, filled grain per panicle, spikelet sterility 1000-grain weight and grain yield indicated great scope for improvement these traits by selection to improve the potentiality of grain yield.

Table 1. Genetic parameter for morphological attributes of some exotic and locally developed rice hybrids.

\begin{tabular}{lllllllllll}
\hline Characters & Range & $\mathrm{MS}$ & $\sigma^{2} \mathrm{~g}$ & $\sigma^{2} \mathrm{e}$ & $\sigma^{2} \mathrm{p}$ & $\mathrm{GCV}$ & $\mathrm{PCV}$ & $\mathrm{h}_{\mathrm{b}}^{2}$ & GA & GAPM \\
\hline PH & $87.35-102.97$ & $78.26^{* *}$ & 25.96 & 0.38 & 26.34 & 5.34 & 5.38 & 98.58 & 10.42 & 8.13 \\
DFF & $110.33-127.00$ & $76.52^{* *}$ & 25.36 & 0.43 & 25.79 & 4.31 & 4.34 & 98.33 & 10.29 & 6.75 \\
ET/h & $5.49-10.27$ & $5.20^{* *}$ & 1.71 & 0.06 & 1.77 & 18.03 & 18.33 & 96.69 & 2.65 & 28.00 \\
PL & $18.23-23.35$ & $6.93^{* *}$ & 2.29 & 0.06 & 2.35 & 7.12 & 7.20 & 97.71 & 3.08 & 11.12 \\
DTM & $137.00-153.00$ & $77.81^{* *}$ & 21.34 & 13.8 & 35.14 & 3.23 & 4.15 & 60.71 & 7.41 & 3.98 \\
FG/P & $128.78-191.97$ & $989.06^{* *}$ & 328.75 & 2.81 & 331.56 & 11.59 & 11.64 & 99.15 & 37.19 & 18.24 \\
SS & $17.32-52.57$ & $349.43^{* *}$ & 115.50 & 2.93 & 118.43 & 29.87 & 30.25 & 97.52 & 21.86 & 46.60 \\
TGW & $19.24-25.10$ & $8.62^{* *}$ & 2.84 & 0.10 & 2.94 & 7.40 & 7.53 & 96.57 & 3.41 & 11.50 \\
GY & $7.09-9.65$ & $1.41^{* *}$ & 0.46 & 0.03 & 0.49 & 7.83 & 8.08 & 94.09 & 1.36 & 12.01 \\
\hline
\end{tabular}

$\mathrm{PH}=$ Plant height $(\mathrm{cm}), \mathrm{DFF}=$ Days to $50 \%$ flowering (days), ET/h = Effective tiller per hill (no.), PL = Panicle length $(\mathrm{cm}), \mathrm{DTM}=$ Days to maturity (days), FG/P = Filled grain per panicle (no), $\mathrm{SS}=$ Spikelet sterility $(\%), \mathrm{TGW}=$ Thousand grain weight $(\mathrm{g})$, and $\mathrm{GY}=$ grain Yield $(\mathrm{t} / \mathrm{h})$.

$* *=$ Significant at $1 \%$ level, $\sigma^{2} \mathrm{~g}=$ Genotypic variance, $\sigma^{2} \mathrm{e}=$ Environmental variance, $\sigma^{2} \mathrm{p}=$ Phenotypic variance, $\mathrm{GCV}=$ Genotypic coefficients of variations, $\mathrm{PCV}=$ Phenotypic coefficients of variations, $\mathrm{h}_{\mathrm{b}}^{2}=$ Heritability in broad sense, $\mathrm{GA}=$ Genetic advance, GAPM $=$ Genetic advance percent of mean.

The values of heritability estimates were high for all the traits and ranged from $60.71 \%$ for days to maturity to $99.15 \%$ for filled grain per panicle. These results were in agreement with the reports of Idris et al. (2013) for number of filled grains per panicle, days to maturity, 1000-seed weight, panicle length and plant height. Genetic variability for productive tiller per plant and number of grains per panicle was reported by Singh et al. (2012). High heritability values in rice were also observed by Roy et al. (2015). The high value of heritability for all the traits suggests that all these traits are under genetic control, i.e. less environmental influence. High heritability alone is not enough to make sufficient improvement through selection generally in advance generations unless accompanied by substantial amount of genetic advance (Bhargava et al. 2003). The efficacy of heritability is increased with the estimation of genetic advance, which indicates the degree of gain in a trait obtained under a particular selection pressure.

But, in the present study, the magnitude of genotypic variance and phenotypic variances was quit close due to lesser role of environmental effect $(\mathrm{Ve}=\mathrm{Vp}-\mathrm{Vg})$. Therefore, all the traits were under the control of genotypic variance (additive + non-additive).

However, in general, it is considered that if a trait is governed by non-additive gene action, it may give high heritability but low genetic advance, whereas if the trait is governed by additive gene action, heritability and genetic advance both would be high. The expected genetic advance as per cent of mean varied from $3.98 \%$ for days to maturity to $46.60 \%$ for spikelet sterility. The highest expected genetic advance was exhibited for spikelet sterility (46.60) followed by effective tiller per hill (28.00), filled grain per panicle (18.24), grain yield (12.01), 1000-grain weight (11.50) and panicle length (11.12). These traits, which showed moderate to high coefficient of variation and high heritability values, indicated a major role of additive gene action in the 
inheritance of these traits and their amenability for improvement in the population for grain yield and its component traits.

Character association analysis among grain yield and yield contributing character (Table 2) revealed that in most of the cases the genotypic correlation coefficient was higher than the respective phenotypic correlation coefficients. This indicated that the suppressive effect of the environment modified the phenotypic expression of these characters by reducing phenotypic correlation values. Roy et al. (2015) also reported higher magnitude of genotypic correlation than respective phenotypic correlations between various characters in rice. Grain yield had significant positive correlation with effective tillers per hill $\left(0.937^{* *}\right)$, panicle length $\left(0.998^{* *}\right)$, filled grain per panicle $\left(0.913^{* *}\right)$ and thousand grain weight $\left(0.997^{* *}\right)$ and significant negative correlation with days to $50 \%$ flowering $\left(-0.645^{* *}\right)$, days to maturity $\left(-0.648^{* *}\right)$ and spikelet sterility $(-0.862 * *)$. The positive correlation of grain yield with various traits were supported by the finding of earlier workers viz. for 1000-grain weight, for effective tillers per $\mathrm{m}^{2}$ and panicle length (Roy et al. 2015), for productive tiller per plant (Gapikannan and Ganesh 2013) and for number of grains per panicle (Vanisree et al. 2013).

Table 2. Genotypic $\left(r_{g}\right)$ and phenotypic $\left(r_{p}\right)$ correlation coefficient for morphological attributes of some exotic and locally developed hybrids.

\begin{tabular}{|c|c|c|c|c|c|c|c|c|c|}
\hline Characters & & DFF & $\mathrm{ET} / \mathrm{h}$ & PL & DTM & FG/P & SS & TGW & GY \\
\hline \multirow[t]{2}{*}{$\mathrm{PH}$} & $r_{g}$ & -0.109 & 0.247 & 0.188 & -0.151 & 0.241 & -0.270 & 0.192 & 0.151 \\
\hline & $r_{p}$ & -0.080 & 0.221 & 0.191 & 0.020 & 0.208 & -0.253 & 0.161 & 0.186 \\
\hline \multirow[t]{2}{*}{ DFF } & $r_{g}$ & & $-0.782^{* *}$ & $-0.715^{* *}$ & $0.986^{* *}$ & $-0.717^{* *}$ & $4.294^{* *}$ & $-0.697^{* *}$ & $-0.645^{* *}$ \\
\hline & $r_{p}$ & & $-0.757^{* *}$ & $-0.703^{* *}$ & $0.777^{* *}$ & $-0.707^{* * *}$ & $0.655^{* *}$ & $-0.675^{* *}$ & $-0.613^{* * *}$ \\
\hline \multirow[t]{2}{*}{$\mathrm{ET} / \mathrm{h}$} & $\mathrm{r}_{\mathrm{g}}$ & & & $0.952^{* *}$ & $-0.757^{* *}$ & $0.970^{* *}$ & $-0.929^{* * *}$ & $0.944^{* *}$ & $0.937^{* *}$ \\
\hline & $r_{p}$ & & & $0.919^{* *}$ & $-0.564^{* *}$ & $0.959^{* *}$ & $-0.905^{* *}$ & $0.927^{* *}$ & $0.871^{* *}$ \\
\hline \multirow[t]{2}{*}{ PL } & $r_{g}$ & & & & $-0.688^{* *}$ & $0.934^{* *}$ & $-0.895^{* *}$ & $0.993^{* *}$ & $0.928^{* *}$ \\
\hline & $r_{p}$ & & & & $-0.521^{*}$ & $0.916^{* *}$ & $-0.868^{* * *}$ & $0.973^{* *}$ & $0.951^{* *}$ \\
\hline \multirow[t]{2}{*}{ DTM } & $r_{g}$ & & & & & $-0.674^{* * *}$ & $0.619^{* *}$ & $-0.680^{* * *}$ & $-0.648^{* *}$ \\
\hline & $r_{p}$ & & & & & $-0.512^{*}$ & $0.479^{* *}$ & $-0.505^{* *}$ & $-0.484^{* * *}$ \\
\hline \multirow[t]{2}{*}{$\mathrm{FG} / \mathrm{P}$} & $r_{g}$ & & & & & & $-0.960^{* * *}$ & $0.936^{* *}$ & $0.913^{* *}$ \\
\hline & $r_{p}$ & & & & & & $-0.946^{* *}$ & $0.921^{* *}$ & $0.873^{* *}$ \\
\hline \multirow[t]{2}{*}{ SS } & $r_{g}$ & & & & & & & $-0.896^{* *}$ & $-0.862^{* * *}$ \\
\hline & $r_{p}$ & & & & & & & $-0.869^{* *}$ & $-0.824^{* * *}$ \\
\hline \multirow[t]{2}{*}{ TGW } & $r_{g}$ & & & & & & & & $0.937^{* *}$ \\
\hline & $r_{p}$ & & & & & & & & $0.949^{* *}$ \\
\hline
\end{tabular}

$* *=$ Significant at $1 \%$ level and $*=$ Significant at $5 \%$ level, $\mathrm{PH}=$ Plant height $(\mathrm{cm})$, DFF $=$ Days to $50 \%$ flowering (days), ET/h = Effective tillers per hill (no.), PL = Panicle length $(\mathrm{cm}), \mathrm{DTM}=$ Days to maturity (days), FG/P = Filled grain per panicle (no), $\mathrm{SS}=$ Spikelet sterility $(\%), \mathrm{TGW}=$ Thousand grain weight $(\mathrm{g})$, and $\mathrm{GY}=$ Grain Yield $(\mathrm{t} / \mathrm{h})$.

Effective tillers per hill had significant positive association with panicle length $(0.952 * *)$, filled grain per panicle $(0.970 * *)$ and 1000 -grain weight $(0.944 * *)$. Panicle length had significant positive association with filled grain per panicle $(0.934 * *)$ and 1000 -grain weight $\left(0.993^{* *}\right)$. 
Filled grain per panicle had significant positive correlation coefficient with 1000-grain weight $\left(0.936^{* *}\right)$. Days to $50 \%$ flowering showed significant negative correlation coefficient with effective tiller per hill $\left(-0.782^{* *}\right)$, panicle length $\left(-0.715^{* *}\right)$, filled grain per panicle $\left(-0.717^{* *}\right)$ and 1000 -grain weight $\left(0.697^{* *}\right)$.

Days to 50\% flowering had significant and negative association with thousand grain weight (Bhadru et al. 2011). Pleiotropy or linkage may also be the genetic reasons for this type of negative association. Plant height had insignificant genotypic correlation among grain yield and all yield contributing traits indicated that selection for high plant height might be possible without compromising yield loss. High linkage between grain yield and its contributing traits were found due to highly significant correlation coefficient values.

The correlation coefficient is inadequate to interpret the cause and effect relationships among the traits and ultimately with yield. Path analysis technique furnishes a method partitioning the correlation coefficients into direct and an indirect effect provides the information on actual contribution of a trait on the yield. The path coefficient analysis revealed that 1000-grain weight (0.729) had the maximum direct effect on grain yield (Table 3). High positive direct effect for 1000-grain weight has been reported by Sinha et al. (2015) and for productive tiller per plant by Manikyaminnie et al. (2013). It was interesting that path coefficient analysis results confirmed the similarity of the correlation coefficient analysis results, which indicated that indirect causal factors are to be considered and optimum height is required for increasing yield.

Table 3. Partitioning of genotypic correlation into direct (bold) and indirect effect for morphological attributes of some exotic and locally developed hybrids.

\begin{tabular}{llllllllll}
\hline Characters & \multicolumn{9}{c}{ Effect through } \\
\cline { 2 - 10 } & PH & DFF & ET/h & PL & DTM & FG/P & SS & TGW \\
\hline PH & $\mathbf{0 . 5 0 0}$ & -0.238 & -0.165 & -0.095 & -0.103 & -0.063 & -0.031 & -0.480 & 0.151 \\
DFF & 0.489 & $-\mathbf{0 . 2 4 4}$ & -0.162 & -0.099 & -0.106 & -0.060 & -0.029 & -0.502 & $-0.645^{* *}$ \\
ET/h & -0.393 & 0.188 & $\mathbf{0 . 2 1 0}$ & 0.132 & 0.079 & 0.081 & 0.04 & 0.683 & $0.937 * *$ \\
PL & -0.339 & 0.173 & 0.198 & $\mathbf{0 . 1 4 0}$ & 0.073 & 0.078 & 0.388 & 0.727 & $0.928^{* *}$ \\
DTM & 0.436 & -0.218 & -0.142 & -0.086 & $\mathbf{- 0 . 1 1 8}$ & -0.513 & -0.245 & -0.442 & $-0.648^{* *}$ \\
FG/P & -0.371 & 0.173 & 0.203 & 0.130 & 0.072 & $\mathbf{0 . 0 8}$ & 0.042 & 0.678 & $0.913^{* *}$ \\
SS & 0.356 & -0.162 & -0.194 & -0.124 & -0.066 & -0.08 & $-\mathbf{0 . 0 4 3}$ & -0.646 & $-0.862^{* *}$ \\
TGW & -0.330 & 0.168 & 0.197 & 0.140 & 0.071 & 0.078 & 0.038 & $\mathbf{0 . 7 2 9}$ & $0.937 * *$ \\
\hline
\end{tabular}

Residual Effect $=0.1031, * *=$ Significant at $1 \%$ level, $\mathrm{PH}=$ Plant height $(\mathrm{cm})$, DFF $=$ Days to $50 \%$ flowering (days), ET/h = Effective tillers per hill (no.), $\mathrm{PL}=$ Panicle length $(\mathrm{cm}), \mathrm{DTM}=$ Days to maturity (days), FG/P = Filled grain per panicle (no), SS = Spikelet sterility (\%), TGW = Thousand-grain weight (g), and $\mathrm{GY}=$ Grain yield $(\mathrm{t} / \mathrm{h})$.

Bornare et al. 2014 reported the moderate positive direct effect for plant height. The effective tillers per hill (0.210) showed moderate positive direct effect on grain yield. Panicle length $(0.140)$ exhibit considerable positive direct effects on grain yield. Its indirect effect through 1000-grain weight was positive and high. This resulted significant positive correlation with grain yield. Panicle length had very low negative direct effect on grain yield was reported by Kole et al. (2008). Filled grain per panicle (0.08) showed negligible direct effect but indirect positive effect via 1000 -grain weight made positively significant genotypic correlation with yield $\left(0.913^{* *}\right)$. 
Days to $50 \%$ flowering $(-0.244)$, days to maturity $(-0.118)$ and spikelet sterility $(-0.043)$ had moderate to low negative direct effect and significant negative correlation. Direct selection based on these three traits would be effective because short duration rice is desirable. Very low residual effects (0.1031) indicated that eight characters included in this study explained high percentage of variation in grain yield. Based on mean, range, genetic parameters, correlation coefficient values and path coefficient values direct selection through, effective tiller per hill, panicle length, filled grain per panicle and 1000-grain weight would significantly improve the grain yield of rice. Concomitant selection based on plant height would be effective for improvement of rice yield. Therefore, emphasis should be given on these characters for the selection of genotypes for higher grain yield in hybrid rice.

\section{References}

Bhadru D, Reddy DL and Ramesha MS 2011. Correlation and path coefficient analysis of yield and yield contributing traits in rice hybrids and their parental lines. Electronic J. Plant Breed. 2(1): 112-116.

Bhargava A, S Shukla, RS Katiyar and Ohri D 2003. Selection parameters for genetic improvement in Chenopodium grain on sodic soil. J. Applied Horticult. 5: 45-48.

Bornare SS, Mittra SK and Mehta AK 2014. Genetic variability, correlation and path analysis of floral, yield and its component traits in CMS and restorer lines of rice (Oryza sativa L.). Bangladesh J Bot. 43: 45-52.

Burton GW 1952. Quantities inheritance in grasses, Proc. $6^{\text {th }}$ Int. grassland congress 1: 277-283.

Dewey DR and Lu KH 1959. A correlation and path co-efficient analysis of components of crested wheat grass seed production, Agron. J. 15: 515-518.

Gopikannan M and Ganesh SK 2013. Inter-relationship and path analysis in rice (Oryza sativa L.) under sodicity. Ind. J. Sci. and Tech. 6: 5223-5227.

Idris AE and Mohamed KA 2013. Estimation of genetic variability and correlation for grain yield components in rice (Oryza sativa L.). Global J. Plant Ecophysiology 3: 1-6.

Johnson HW, Robinson HF and Comstock RE 1955 (a). Estimates of genetic and environmental variability in soybean. Agronomy Journal 47: 314-318.

Kabir MS, Salam MU, Chowdhury A, Rahman NMF, Iftekharuddaula KM, Rahman MS, Rashid MH, Dipti SS, Islam A, Latif MA, Islam AKMS, Hassain MM, Nessa B, Ansari TH, Ali MA and Biswas JK 2015. Rice vision for Bangladesh: 2050 and beyond. Bangladesh Rice Journal 19: 1-18.

Kole PC, Chakraborty NR and Bhat JS 2008. Analysis of variability, correlation and path coefficients in induced mutants of aromatic non-basmati rice. Tropical Agricultural Research \& Extension 11: 60-64.

Manikyaminnie C, Dayakar Reddy T and Surendra Raju Ch. 2013. Correlation and path analysis for yield and its components in rice (Oryza sativa L.). J. Res. ANGRAU. 41: 132-134.

Miller PJ, Willianis JC, Robinson HF and Comostock RE 1958. Estimates of genotypic and environmental variance and covariance in upland cotton and their implication in selection. Agron. J. 50: 126-131.

Mohsin T, Khan N and Naqvi FN 2009. Heritability, phenotypic correlation and path coefficient studies for some agronomic characters in synthetic elite lines of wheat. J. Food Agri. and Envi. 7: 278-282.

Prasad B, Patwary AK and Biswas PS 2001. Genetic variability and selection criteria in fine rice (Oryza sativa L.). Pakistan J. Biol. Sci. 4:1188-1190.

Roy RK, Majumder RR, Sultana S, Hoque ME and Ali MS 2015. Genetic variability, correlation and path coefficient analysis for yield and yield components in transplant aman rice (Oryza sativa L.), Bangladesh J. Bot. 44: 529-535.

Sameera SK, Srinivas T, Rajesh AP, Jayalakshmi V and Nirmala PJ 2016. Variability and path co-efficient for yield and yield components in rice. Bangladesh J. Agril. Res. 41: 259-271.

Sharma CL and Sharma RN 2007. Genetic variability and character association in early maturing rice. Oryza 44(4): 300-303.

Sinha AK, Tiwari TN, Singh D and Tripathi JK 2015. Correlation and path co-efficient analysis for genetic response of seed yield traits at varying spacing in rice cultivars. Oryza 52(4): 313-317. 
Singh PK, Dhakad BK, Singh HB and Singh AK 2012. Genetic variability and association analysis in rice (Oryza sativa L.) treated with Trichoderma harzianum. Crop Res. 44: 141-145.

Vanisree S, Anjali K, Damodar Raju Ch., Surender Raju Ch. and Sreedhar M 2013. Variability, heritability and association analysis in scented rice. J. Bio. Sci. 1: 347-352.

Wright S 1934. The method of path coefficient. Annals of Mathematical Statistics 5: 161-215.

(Manuscript received on 7 September, 2018; revised on 23 February, 2019) 